\title{
Exclusion of mimics does not influence Willis-Ekbom disease diagnosis among recent medical graduates
}

\author{
Exclusão de fatores confundidores não influencia o diagnóstico da doença de \\ Willis-Ekbom entre recém-formados em Medicina
}

Karla Carlos ${ }^{1}$, Gilmar Fernandes do Prado ${ }^{1}$

\begin{abstract}
In view of the diagnostic challenge posed by restless legs syndrome/Willis-Ekbom disease (RLS/WED) to health professionals and the challenge of its recognition by patients, the diagnostic criteria have been revised and updated to facilitate identification of this disease. However, in a previous study, we found that self-diagnosis of RLS/WED depends on the very name used to describe the condition. Objective: To ascertain whether the presence of the fifth diagnostic criterion of the International Restless Legs Syndrome Study Group (IRLSSG), is necessary for RLS/WED diagnosis when the term "Willis-Ekbom disease" is used. Methods: We randomly distributed 705 forms to recent medical graduates, asking them to self-assess whether they had "Willis-Ekbom disease" (WED). In one questionnaire model, we excluded the fifth criterion suggested by the IRLSSG, while in the other, all five criteria were included. No forms contained the term RLS; only WED was used throughout. Results: Seven hundred and five recent medical graduates participated in the study. Among the 332 who received the form without the fifth criterion, $8(2.41 \%)$ self-diagnosed as having WED ( $95 \% \mathrm{Cl}: 0.8 \%-4.1 \%)$. Of the 373 who received the form with all five of the 2014 IRLSSG criteria, 9 (2.41\%) self-diagnosed as having WED ( $95 \% \mathrm{Cl}$ : $0.8 \%-4.0 \%)(p>0.05)$. Conclusion: Our data show that presence of the fifth IRLSSG criterion did not influence self-diagnosis of WED among recent medical graduates, suggesting that the name WED reduces the odds of mimics (confounding conditions) being misinterpreted as symptoms of this disease. This finding indicates that for the diagnosis of RLS/WED only four criteria and a systematic use of the name WED are necessary.
\end{abstract}

Keywords: Restless legs syndrome; Willis-Ekbom disease; diagnosis.

\section{RESUMO}

Frente ao desafio diagnóstico da síndrome das pernas inquietas/doença de Willis-Ekbom (SPI/DWE) pelos profissionais de saúde e também seu reconhecimento pelos pacientes, os critérios de diagnóstico vêm sendo revisados e atualizados para facilitar a identificação dessa doença, porém, em estudo anterior, observamos que o autodiagnóstico da SPI/DWE depende do próprio nome utilizado para descrevê-la. Objetivo: Verificar se a presença do quinto critério do International Restless Legs Syndrome Study Group (IRLSSG) é necessária para o diagnóstico da SPI/DWE quando utilizamos apenas a expressão/denominação DWE. Métodos: Distribuímos aleatoriamente 705 formulários solicitando a médicos recém-formados que avaliassem se eles tinham DWE. Em um tipo de questionário, excluímos o quinto critério diagnóstico sugerido pelo IRLSSG e no outro mantivemos os cinco critérios. Em nenhum formulário apresentamos o termo SPI, apenas DWE. Resultados: Setecentos e cinco médicos recém-formados participaram do estudo. Dentre os 332 médicos que receberam o formulário sem o quinto critério, 8 (2,41\%) autodiagnosticaram-se com DWE (IC 95\%: 0,8\%-4,1\%). Trezentos e setenta e três médicos receberam o formulário com os 5 critérios do IRLSSG (2014) e 9 (2,41\%) autodiagnosticaram-se como tendo DWE (IC 95\%: 0,8\%-4,0\%) ( $p>0.05$ ). Conclusão: Nossos dados mostraram que a presença do quinto critério do IRLSSG não influenciou a realização do autodiagnóstico da DWE entre médicos recém-formados, sugerindo que a denominação DWE reduz a chance de condições confundidoras serem tomadas como sintomas desta doença. Este achado está de acordo com dados anteriores, onde mostramos que o autodiagnóstico da SPI/DWE é dependente da denominação utilizada para descrever a doença.

Palavras-chave: Síndrome das pernas inquietas; doença de Willis-Ekbom; diagnóstico.

Restless legs syndrome/Willis-Ekbom disease (RLS/WED) is a highly-prevalent disease but is still little known, both by health professionals and by the population ${ }^{1,2}$. It causes a great negative impact on quality of life ${ }^{3}$, and every physician should be able to at least establish the diagnosis, as the complaints suggestive of this disease are not restricted to a single specialty ${ }^{4}$.

${ }_{1}^{1}$ Universidade Federal de São Paulo, Escola Paulista de Medicina, Departamento de Neurologia, Neuro-Sono, São Paulo SP, Brasil.

Correspondence: Karla Carlos; Rua Claudio Rossi, 394; 01547-000 São Paulo SP, Brasil; E-mail: ka.carlos1@hotmail.com

Conflict of interest: There is no conflict of interest to declare.

Received 19 June 2018; Received in final form 22 August 2018; Accepted 05 September 2018. 
Since the thorough description of RLS/WED by Karl Ekbom $^{5,6}$, the diagnostic criteria have been revised and updated $^{1,2,7,8,9}$ with the objective of facilitating recognition of the disease and reducing false-positive diagnoses ${ }^{10}$. Several clinical conditions ${ }^{10}$ can meet all four diagnostic criteria for RLS/WED ${ }^{2}$ and still not constitute the disease per se. Thus, symptoms that mimic these criteria are confounding factors that affect the proper diagnosis of RLS/WED. Within this context, an attempt was made to facilitate diagnosis of this disease by introducing a fifth criterion (Appendix), which addresses clinical conditions and symptoms important for differential diagnosis; therefore, this criterion reinforces what RLS/WED is not ${ }^{1}$.

In a previous study, we found that replacing the name "restless legs syndrome" with "Willis-Ekbom disease" greatly altered the prevalence of self-diagnosis. This indicates that the name RLS tends to be misinterpreted, particularly because the term "restless" is suggestive of physical and psychological conditions unrelated to the disease, such as the habit of fidgeting or otherwise moving one's legs in different situations of daily life ${ }^{11}$. Our hypothesis is that the use of the name WED is enough to improve diagnostic accuracy, reducing or abolishing the need for the fifth criterion altogether and, consequently, facilitating proper diagnosis.

\section{METHODS}

We studied the impact of the fifth IRLSSG diagnostic criterion on the prevalence of self-diagnosed Willis-Ekbom disease among recent medical graduates applying for residency at a highly-competitive Brazilian university. The respondents were divided into two groups and analyzed their own clinical condition with respect to the diagnosis of WED. One group (All Five group) completed a self-assessment questionnaire that included all five IRLSSG criteria (Appendix), while the other completed a questionnaire with no fifth criterion (No Fifth group).

\section{Population and setting}

For this study, we used the same population of recent medical graduates applying for residency positions at Escola Paulista de Medicina - Universidade Federal de São Paulo, as described in detail in a prior study ${ }^{11}$. Candidates of both sexes, from all regions of Brazil, completed a less than 10-minute long questionnaire in the waiting rooms, while awaiting the start of their residency entrance exams. This was the most appropriate time to approach them, as the candidates had an interval of around 40 minutes between evaluation phases. There was no restriction on age or ethnicity. This study was approved by the Universidade Federal de São Paulo Research Ethics Committee (process number 115.917/2012), and all participants provided written informed consent.

\section{Self-diagnosis of WED}

The participants were instructed to perform a selfassessment of the possibility of having a diagnosis of WED (yes or no), according to criteria proposed by the IRLSSG. One group of participants received a form without the fifth criterion (No Fifth group), while the other received a form containing all five diagnostic criteria for the disease (All Five group).

\section{Randomization}

The investigators randomly distributed two types of forms to the residency exam invigilators. The invigilators were unaware of which forms they were delivering to the study participants, and the distribution was made without any specific rules, depending solely on proximity to the participants or convenience, which further helped ensure randomization.

\section{Statistical analysis}

Data found to be normally distributed on the KolmogorovSmirnov test were analyzed through descriptive statistics. We used the error of the sample proportion, considering a 95\% confidence interval (95\%CI), to analyze the variability of the sample. The Student's $t$-test was used to compare mean age between groups, while the chi-square test was used to compare the proportion of self-diagnosis.

\section{RESULTS}

\section{Demographic data}

We invited 783 recent medical graduates to take part in the study. Of these, 705 agreed to participate and 78 (10\%) did not. Among the 705 participants, 360 (51.06\%) were women (95\%CI: 47.32\%-54.68\%) and 345 (48.94\%) were men (95\%CI: $45.25 \%-52.69 \%)$, with no statistically significant difference between genders ( $p>0.05$ ) (Table). The All Five and No Fifth subgroups also did not differ regarding age and sex.

\begin{tabular}{|c|c|c|c|c|}
\hline Variables & $\mathrm{N}$ & $\%$ & $95 \% \mathrm{Cl}$ & $\mathrm{p}$ \\
\hline \multicolumn{5}{|c|}{ All participants } \\
\hline Women & 360 & 51.06 & $47.32 \%-54.68 \%$ & \multirow{2}{*}{$>0.05$} \\
\hline Men & 345 & 48.94 & $45.25 \%-52.69 \%$ & \\
\hline \multicolumn{5}{|c|}{ Stratification of participants into groups All-Five and No-Fifth } \\
\hline \multicolumn{5}{|c|}{ All-Five Group } \\
\hline Women & 190 & 51 & $45.93 \%-56.07 \%$ & \multirow{2}{*}{$>0.05$} \\
\hline Men & 183 & 49 & $43.93 \%-54.07 \%$ & \\
\hline \multicolumn{5}{|c|}{ No-Fifth Group } \\
\hline Women & 170 & 51.20 & $45.90 \%-56.50 \%$ & \multirow{2}{*}{$>0.05$} \\
\hline Men & 162 & 48.94 & $43.57 \%-54.31 \%$ & \\
\hline
\end{tabular}




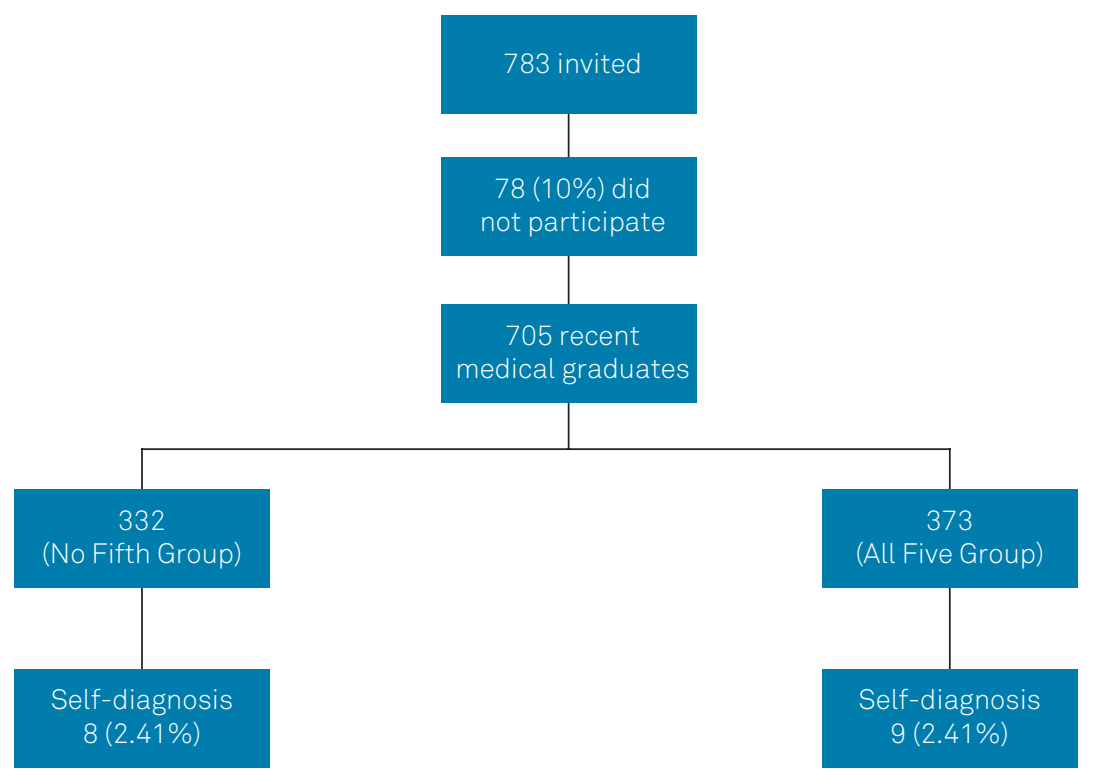

Figure. Self-diagnosis of WED without vs. with the fifth IRLSSG diagnostic criterion.

\section{All Five group}

Three hundred and seventy-three recent medical graduates, with a mean age of $26 \pm 3$ years, received the form containing all five IRLSSG criteria and answered the question: “Do you have Willis-Ekbom disease?". Among these, 190 (51\%) were female (95\%CI: 45.93\%-56.07\%) and $183(49 \%)$ were male (95\%CI: 43.93\%-54.07\%) (Table).

In this group, 9 (2.41\%) (95\%CI: $0.8 \%-4.0 \%)$ physicians self-diagnosed WED:4 women (44.44\%; 95\% CI 11.98\%-76.90\%) and 5 men (55.56\%; 95\%CI: 23.10\%-88.02\%) (Figure).

\section{No Fifth group}

Three hundred and thirty-two recent medical graduates received the form without the fifth IRLSSG criterion and answered the question: "Do you have Willis-Ekbom disease?". Of these, 170 (51.20\%) were female (95\%CI: 45.90\%-56.50\%) and $162(48.94 \%)$ were male (95\%CI: 43.57\%-54.31\%) (Table). The mean age in this group was $26 \pm 2$ years.

In this group, 8 respondents self-diagnosed with WED (2.41\%) (95\%CI: $0.8 \%-4.1 \%)$ : 5 women $(62.50 \%$; $95 \%$ CI: 28.96\%-96.04\%) and 3 men (37.50\%; 95\%CI: 3.96\%-71.04\%). The prevalence of self-diagnosis of WED did not differ between men and women (Figure).

The proportion of respondents who self-diagnosed with WED per four diagnostic criteria (No Fifth group) did not differ from that of respondents who used all five diagnostic criteria (All Five group) $(p>0.05)$. The proportions of diagnosis of WED did not differ by sex.

\section{DISCUSSION}

In this study, we demonstrated that the presence of the fifth criterion proposed by the IRLSSG in $2014^{1}$ was not relevant for self-diagnosis of WED among recent medical graduates. We used the self-diagnosis strategy as a motivation tool, aiming to obtain maximal attention from the participants. This study was not designed to explore the prevalence of RLS/WED.

In a previous study, we showed that the different names given to this disease altered the prevalence of self-diagnosis, which was much higher when using the expression "RLS"11. As discussed previously, the term "restless", in particular, promotes a major change in the way the individual perceives information; their own experiences and concepts alter the meaning associated with the word. The fifth diagnostic criterion is thus only necessary because of the use of the term "restless legs syndrome".

Diagnosis of RLS is based on the patient's report. However, symptoms that mimic the disease may be present $^{10}$, including cramping, positional discomfort, pain, and local leg pathology $\mathrm{y}^{12}$, as these may satisfy all four criteria for diagnosis of RLS. To improve diagnostic specificity, these clinical conditions must be ruled out ${ }^{12}$. Hence, the addition of the fifth diagnostic criterion in 2014. In other words, the fifth criterion aims to facilitate recognition of the disease by characterizing what it is not, to define it in its full clinical and technical sense.

There are several controversies regarding the use of eponyms (from the Greek epi, "upon", and onyma, "name"). However, in the case of WED, the eponymous term has several advantages, including obviating the need for an additional diagnostic criterion, thus streamlining recognition and treatment of this very common disease.

Furthermore, there is still much ignorance about this condition among physicians and the general population. When healthcare providers are faced with the expression "restless legs syndrome", the term "restless" calls to mind 
meanings that do not represent WED accurately. This prevents clinicians from seeking more information about the disease and asking patients for a detailed description of their symptoms, as the clinicians' own experiences with the term "restless" lead them to assume they are knowledgeable about the condition and thus neglect its true technical definition ${ }^{11}$; the term "Willis-Ekbom disease" is not associated with such preconceived notions.

Another speculated reason why the $5^{\text {th }}$ criterion was not relevant in our present study is related to a possible consecutive understanding of each criterion as the participant reads the sequence of items, allowing them to complete their understanding even before they reach the $5^{\text {th }}$ criterion.

Our study has some strength since we randomly distributed the forms, the population is highly educated making it easier to understand our purpose, we have a large number of participants and, most important, they were physicians (recently graduated) and the main reason and to whom these criteria are finally destined. A possible weakness would be a low probability of some mimics, although positional discomfort, and habitual foot tapping are the most relevant confounders and frequently reported in this population, according to our data from our previous study.

In summary, our study suggests that the fifth IRLSSG criterion is unnecessary when using the expression WED in a population of recently graduated physicians, reinforcing the need for and importance of introducing it into daily clinical practice. In addition to giving this highly impactful condition the seriousness it deserves, this shift would motivate clinicians to understand its true symptoms, facilitate and streamline diagnosis, and prevent derogatory and degrading remarks related to the expression "restless legs".

\section{ACKNOWLEDGMENTS}

CNPq - Conselho Nacional de Desenvolvimento Científico e Tecnológico (The National Council for Scientific and Technological Development). CAPES - Coordenação de Aperfeiçoamento de Pessoal de Nível Superior (Coordination for the Improvement of Higher Education Personnel).

\section{References}

1. Allen RP, Picchietti DL, Garcia-Borreguero D, Ondo WG, Walters AS, Winkelman JW et al. Restless legs syndrome/Willis-Ekbom disease diagnostic criteria: updated International Restless Legs Syndrome Study Group (IRLSSG) consensus criteria: History, rationale, description, and significance. Sleep Med. 2014 Aug;15(8):860-73. https://doi.org/10.1016/j.sleep.2014.03.025

2. Allen RP, Picchietti D, Hening WA, Trenkwalder C, Walters AS, Montplaisir J. Restless legs Syndrome: diagnostic criteria, special considerations, and epidemiology.. Sleep Med. 2003;4(2):101-19. https://doi.org/10.1016/S1389-9457(03)00010-8

3. Varela MJ, Coin-Carvalho JE, Carvalho LB, Varela MV, Potasz C, Prado LB et al. Restless legs syndrome: a qualitative analysis of psychosocial suffering and interdisciplinary attention.J Health Psychol. 2013 Oct;18(10):1341-52. https://doi.org/10.1177/1359105312439730

4. Nichols DA, Allen RP, Grauke JH, Brown JB, Rice ML, Hyde PR et al. Restless legs syndrome symptoms in primary care: a prevalence study. Arch Intern Med. 2003 Oct;163(19):2323-9. https://doi.org/10.1001/archinte.163.19.2323

5. Ekbom KA. Athenia crurum paraesthetica (irritable legs). Acta Med Scand. 1944;121:18-59.

6. Ekbom KA. Restless legs syndrome. Neurology. 1960 Sep;10(9):868-73. https://doi.org/10.1212/WNL.10.9.868
7. Sleep Disorders Classification Committee, Association of Sleep Disorders Centes. Diagnostic classification of sleep and arousal disorders. Sleep. 1979;2:1-154.

8. American Sleep Disorders Association. Diagnostic Classification Steering Committee. The international classification of sleep disorders: diagnostic and coding manual. Rochester (MN): ASDA; 1990.

9. Walters AS, Aldrich MS, Allen R, Ancoli-Israel S, Buchholz D, Chokroverty S, et al.; The International Restless Legs Syndrome Study Group. Toward a better definition of the restless legs syndrome. Mov Disord. 1995 Sep;10(5):634-42. https://doi.org/10.1002/mds.870100517

10. Benes H, Walters AS, Allen RP, Hening WA, Kohnen R. Definition of restless legs syndrome, how to diagnose it, and how to differentiate it from RLS mimics. Mov Disord. 2007;22(S18 Suppl 18):S401-8. https://doi.org/10.1002/mds.21604

11. Carlos K, Prado LB, Carvalho LB, Prado GF. Willis-Ekbom disease or restless legs syndrome? Sleep Med. 2015 Sep;16(9):1156-9. https://doi.org/10.1016/j.sleep.2015.05.022

12. Hening WA, Allen RP, Washburn M, Lesage SR, Earley CJ. The four diagnostic criteria for Restless Legs Syndrome are unable to exclude confounding conditions (“mimics"). Sleep Med. 2009 Oct;10(9):976-81. https://doi.org/10.1016/j.sleep.2008.09.015 


\section{APPENDIX}

Five essential diagnostic criteria for RLS/WED.

1) An urge to move the legs usually, but not always, accompanied by or felt to be caused by uncomfortable and unpleasant sensations in the legs.

2) The urge to move the legs and any accompanying unpleasant sensations begin or worsen during periods of rest or inactivity such as lying down or sitting.

3) The urge to move the legs and any accompanying unpleasant sensations are partially or totally relieved by movement, such as walking or stretching, at least as long as the activity continues.

4) The urge to move the legs and any accompanying unpleasant sensations during rest or inactivity only occur or are worse in the evening or night than during the day.

5) The occurrence of the above features is not solely accounted for as symptoms primary to another medical or behavioral condition (e.g. myalgia, venous stasis, leg edema, arthritis, leg cramps, positional discomfort, habitual foot tapping). 